p-ISSN 2615-286X | e-ISSN 2798-5075

DOI 1052646

\title{
PENGARUH PROMOSI KESEHATAN TENTANG IMS (INFEKSI MENULAR SEKSUAL) TERHADAP PENGETAHUAN REMAJA DISMA YPK DIASPORA KOTARAJA JAYAPURA
}

\author{
Martha Loho, Rifki Sakinah Nompo ${ }^{2}$, Arvia $^{3}$ \\ ${ }^{1)}$ Mahasiswa S1 Keperawatan STIKES Jayapura \\ ${ }^{2)}$ Prodi Pendidikan Profesi Ners STIKES Jayapuraa \\ ${ }^{3)}$ Prodi S1 Keperawatan STIKES Jayapuraa \\ email:marthaloho92@gmail.com
}

\begin{abstract}
ABSTRAK
Latar Belakang: Infeksi Menular Seksual (IMS) adalah penyakit infeksi yang penularannya terutama melalui hubungan seksual, sampai saat ini masih merupakan masalah kesehatan masyarakat di seluruh dunia, baik di negara maju maupun di negara berkembang. Penyakit menular seksual yang menyerang organ seksual itu meliputi klamidia, gonore, trikomoniasis, dan sifilis. Tujuan Penelitian: Mengetahui pengaruh promosi kesehatan tentang IMS (Infeksi Menular Seksual) terhadap pengetahuan Remaja di SMA YPK Diaspora Kotaraja Jayapura. Metode Penelitian: Jenis penelitian ini menggunakan metode Quasi Eksperimen One Group Pre Test-Post Test, dengan menggunakan uji analisa Wilcoxon. Penelitian ini dilaksanakan pada bulan September-Oktober 2020. Menggunakan total sampling 45 responden sebagai sampel. Kuesioner yang digunakan berjumlah 20 item peryataan. Hasil: Pengaruh promosi kesehatan terhadap pengetahuan remaja terhadap Infeksi Menular Seksual, sebelum dilakukannya promosi kesehatan mengenai IMS, sebanyak 2 responden (4.4\%) memiliki pengetahuan baik, 14 responden (31.3\%) memiliki pengetahuan cukup, dan 29 responden $(64.4 \%)$ memiliki pengetahuan kurang dan setelah dilakukannya promosi kesehatan mengenai IMS, sebanyak 17 responden (37.8\%) memiliki pengetahuan baik, 20 responden (44.4\%) memiliki pengetahuan cukup, dan 8 responden $(17,8 \%)$ memiliki pengetahuan kurang. Hasil pengaruh menggunakan uji Wilcoxon $\rho=0,000<0.05$. Kesimpulan: Penelitian ini menyimpulkan ada pengaruh yang signifikan antara promosi kesehatan terhadap pengetahuan remaja mengenai Infeksi Menular Seksual setelah dilakukannya promosi kesehatan.
\end{abstract}

Kata Kunci: Infeksi Menular Seksual (IMS), Promosi Kesehatan, Pengetahuan remaja, Remaja.

\section{ABSTRACT}

Background: Sexually Transmitted Infections (STI) is an infectious disease that is transmitted mainly through sexual contact, until now it is still a public health problem throughout the world, both in developed and developing countries. Sexually transmitted diseases that attack sexual organs include chlamydia, gonorrhea, trichomoniasis and syphilis. Research Objectives: To determine the effect of health promotion on STI (Sexually Transmitted Infections) on the knowledge of adolescents in High School YPK Diaspora, Kotaraja Jayapura. Research Methods: This type of research uses the Quasi Experiment method of One Group Pre Test- Post Test, using test analysis Wilcoxon. This research was conducted in September-October 2020. Using a total sampling of 45 respondents as the sample. The questionnaire used amounted to 20 items of statement. Results: The effect of health promotion on adolescent knowledge on Sexually Transmitted Infections, before the implementation of health promotion regarding STIs, as many as 2 respondents ( $4.4 \%$ ) had good knowledge, 14 respondents ( $31.3 \%)$ had sufficient knowledge, and 29 respondents (64.4\%) had sufficient knowledge. less and after health promotion of STIs , 17 respondents ( $37.8 \%$ ) had good knowledge , 20 respondents ( $44.4 \%)$ had sufficient knowledge, and 8 respondents (17.8\%) had less knowledge. The results of the influence using the Wilcoxon test $\rho=0.000<0.05$. Conclusion: This study concludes that there is a significant influence between health promotion on adolescent knowledge about sexually transmitted infections after health promotion.

Keywords:SexuallyTransmittedInfections(STI),HealthPromotion,YouthKnowledge,Adolescents. 


\section{PENDAHULUAN}

Infeksi Menular Seksual (IMS) adalah penyakit infeksi yang penularannya terutama melalui hubungan seksual, sampai saat ini masih merupakan masalah kesehatan masyarakat diseluruh dunia, baik di negara maju (industri) maupun di negara berkembang (Ervina \& Septiani, 2015).

World Health Organization (WHO, 2019) menyatakan lebih dari satu juta orang di dunia didiagnosis menderita penyakit menular seksual (PMS) setiap harinya. Penyakit menular seksual yang menyerang organ seksual itu meliputi klamidia, gonore, trikomoniasis, dan sifilis. WHO juga menemukan satu dari setiap 25 orang di dunia memiliki setidaknya satu dari penyakit infeksi menular tersebut. Di Indonesia angka IMS saat ini cenderung meningkat, jumlah kasus HIV dari tahun ke tahun cenderung mengalami peningkatan sejak dilaporkannya kasus tersebut yaitu pada tahun 1987. Jumlah kumulatif penderita HIV dari tahun 1987 sampai dengan September 2014 sebanyak 150.296 orang, sedangkan total kumulatif kasus AIDS sebanyak 55.799 orang (Kemenkes RI, 2014).

Menurut data dari Pusat Kesehatan Reproduksi (PKR) kota Jayapura, pada bulan Januari hingga Desember 2015, tercatat sebanyak 1.115 kasus pengidap penyakit IMS. IMS menjadi sebuah pintu masuk penyakit HIV akibat hubungan seks, dan memasukan jari pada rahim atau berhubungan seks melalui anus (Dinkes Kota Jayapura, 2018). Program pencegahan dan pemberantasan infeksi menular seksual harus menjadi prioritas utama, karena infeksi menular seksual merupakan suatu faktor resiko yang tinggi yaitu mempermudah penularan HIV/AIDS, sedangkan infeksi klamidia, ulkus, gonorhoe, uretritis non gonorhoe, sifilis, dan trikomoniasis dapat meningkatkan resiko penularan HIV antara $2-9$ kali. Penderita infeksi menular seksual dengan ulkus genital mempunyai resiko $2-5$ kali dibanding penderita tanpa ulkus (Desi, 2018).

Remaja dan dewasa muda usia (15-24 tahun) hanya merupakan $25 \%$ dari keseluruhan populasi yang aktif berhubungan seksual namun mewakili hampir 50\% kasus baru IMS. Usia muda dan remaja merupakan individu yang paling beresiko untuk tertular PMS karena usia muda, remaja lebih mudah terpengaruh secara tidak proporsional (Daili., et al, 2011).

Beberapa peneliti mengungkapkan bahwa pengetahuan berhubungan dengan IMS. Menurut Astuti (2017) ada hubungan antara tingkat pengetahuan dan IMS dengan sikap pra nikah. Sedangkan menurut Nova (2016) promosi dan pengetahuan mempunyai hubungan yang bermakna dengan kejadian IMS.

Melalui Promosi Kesehatan yang merupakan suatu cara dalam memberikan pendidikan kesehatan, dimana dalam konsep promosi kesehatan bukan hanya proses penyadaran dalam hal ini pemberian dan peningkatan pengetahuan masyarakat dalam bidang kesehatan saja melainkan juga upaya upaya bagaimana mampu menjembatani adanya perubahan perilakuseseorang (Dewi, 2017).

Hasil wawancara kepada siswa remaja didapatkan 3 orang mengerti tentang apa itu IMS dan 3 orang lainnya tidak mengerti bahkan tidak mengetahui tentang apa itu IMS, hal ini dikarenakan belum pernah dilakukan penyuluhan mengenai IMS di SMA YPK Diaspora sebelumnya, dan 3 orang remaja yang mengetahui tentang IMS, mereka hanya mengetahui melalui media elektronik, orang tua dan informasi di Puskesmas terdekat yang berada disekitar tempat tinggal beberapa remaja tersebut.

Berdasarkan latar belakang diatas, menjadi ketertarikan sendiri kepada peneliti untuk meneliti mengenai Pengaruh Promosi Kesehatan Tentang IMS (Infeksi MenularSeksual) Terhadap Pengetahuan Remaja di SMA YPK Diaspora Kotaraja Jayapura.

\section{METODE PENELITIAN}

Desain penelitian yang digunakan dalam penelitian ini menggunakan metode Quasi Eksperimen One Group PreTest-PostTest Non Control Group yaitu penelitian dengan satu subyek yang dilakukan perlakuan atau intervensi sebelum dan sesudah perlakuan (Arikunto, 2012).

Populasi dalam penelitian ini adalah remaja kelas X IPA SMA YPK Diaspora Kotaraja Jayapura yang berjumlah 45 siswa-siswi, Pengambilan sampel menggunakan teknik total sampling, yang terdiri dari kelas IPA 1 yang berjumlah 23 siswa-siswi dan IPA 2 yang berjumlah 22 siswa-siswi. Terdapat 3 instrumen penelitian yang digunakan dalam penelitian ini diantaranya: kuesioner karasteristik responden, pengetahuan IMS dan Video edukasi promosi kesehatan mengenai IMS. Analisa data menggunakan univariat dalam presentase dan bivariat menggunakan uji willcoxon test. 


\section{HASIL PENELITIAN}

\section{Univariat}

Dalam penyajian analisis univariat dibuat menggunakan tabel, diantaranya meliputi karasteristik responden seperti; usia, jenis kelamin dan sumber informasi kesehatan reproduksi.

\begin{tabular}{lcc}
\multicolumn{3}{c}{ Tabel 1 KarakteristikResponden } \\
\hline Karakteristik & Frekuensi & $\%$ \\
\hline Usia & 33 & 73.3 \\
14-16 tahun & 12 & 26.7 \\
17-20 & 45 & 100.0 \\
tahunTotal & & \\
\hline Jenis & 21 & 46.7 \\
Kelamin & 24 & 53.3 \\
Laki-Laki & 45 & 100.0 \\
Perempua & & \\
n & & \\
Total & & \\
Sumber & & \\
Informasi & & 44.4 \\
Kesehatan & 20 & 4.5 \\
Reproduksi & 2 & 26.7 \\
Orang tua & 12 & 24.4 \\
Teman & 11 & 0. \\
Sekolah & 45 & \\
Interne & & \\
tTotal & &
\end{tabular}

Berdasarkan karasteristik menurut usia, dari 45 reponden yang teliti, 33 responden atau $73.3 \%$ berusia antara 14-16 tahun dan sebanyak 12 Responden atau $26.7 \%$ berusia 17-20 tahun. Hal ini menunjukan bahwa sebagian besar reponden berusia diantara 1416 tahun, dan responden paling sedikit berusia diantara 17-20 tahun. Kriteria responden berdasarkan jenis kelamin. Dari 45 reponden yang di teliti, 21 responden atau $46.7 \%$ berjenis kelamin laki-laki dan 24 responden atau $53.3 \%$ berjenis kelamin perempuan. Hal ini menunjukan bahwa sebagian besar reponden berjenis kelamin perempuan, dan responden paling sedikit berjenis kelamin lakilaki. Karakteristik responden berdasarkan sumber infomasi kesehatan reproduksi. Dari 45 reponden, sebanyak 20 responden atau $44.4 \%$ bersumber dari orang tua, sebanyak 2 responden atau $4.5 \%$ bersumber dari teman, 12 responden atau $26.7 \%$ bersumber dari sekolah dan 11 responden atau $24.4 \%$ bersumber dari internet.

Tabel 2 Pengetahuan Responden Sebelum Dilakukan Promosi Kesehatan Tentang IMS

\begin{tabular}{lcc}
\hline \multicolumn{1}{c}{ Kategori } & Frekuensi & Persentase (\%) \\
\hline Tingkat & & \\
Pengetahua & & \\
$\mathrm{n} \quad$ & 2 & 4.4 \\
$\quad$ Baik & 14 & 31.1 \\
Cukup & 29 & 64.4 \\
Kuran & $\underline{45}$ & $\underline{100.0}$ \\
g & & \\
Total & & \\
\hline
\end{tabular}

Berdasarkan pengetahuan responden sebelum dilakukan promosi kesehatan tentang IMS. Diketahui dari 45 responden yang diteliti sebanyak 2 remaja atau $4.4 \%$ memiliki pengetahuan yang baik, 14 remaja atau $31.1 \%$ memiliki pengetahuan cukup, dan 29 remaja atau $64.4 \%$ memiliki pengetahuan kurang. Hal ini menunjukan bahwa lebih darisebagian responden belum dilakukan penyuluhan kesehatan memiliki pengetahuan kurang.

Tabel 3 Pengetahuan Responden Setelah Dilakukanpromosi kesehatan tentang IMS

\begin{tabular}{lcc}
\hline \multicolumn{1}{c}{ Kategori } & Frekuensi & \% \\
\hline Tingkat & & \\
Pengetahuan & 17 & 37.8 \\
Baik & 20 & 44.4 \\
Cukup & 8 & 17.8 \\
Kuran & $\underline{45}$ & $\underline{100.0}$ \\
g & & \\
Total & & \\
\hline
\end{tabular}

. Berdasarkan pengetahuan responden sebelum dilakukan promosi kesehatan tentang IMS. Diketahui dari 45 responden setelah dilakukannya promosi kesehatan mengenai IMS, sebanyak 17 responden atau 37.8\% memiliki kategori pengetahuan baik, dan kategori pengetahuan cukup 20 responden atau $44.4 \%$, dan kategori pengetahuan kurang 8 responden atau $17.8 \%$. Hal ini menunjukkan bahwa sebagian besar responden setalah dilakukan penyuluhan kesehatan memiliki pengetahuan baik dan cukup.

\section{Bivariat}

Analisa bivariat ini, peneliti menggunakan uji Wilcoxon Test untuk mengetahui pengaruh promosi kesehatan tentang Infeksi Menular Seksual terhadap pengetahuan remaja di SMA YPK DiasporaKotarajaJayapura pihak yang sering menjadi korban adalah remaja putri atau perempuan karena mereka sering tidak berdaya untuk menerima rayuan dan paksaan untuk melakukan hubungan seks (Nari J., dkk 2015 
Tabel 4 Analisis Pengaruh Sebelum Dan Setelah Promosi Kesehatan Tentang IMS

\begin{tabular}{|c|c|c|c|}
\hline Variabel & $\begin{array}{l}\text { Mean } \\
\text { Rank }\end{array}$ & Nilai Z & $\begin{array}{l}\text { Asymp. } \\
\text { Sig. } \\
\text { (2-tailed) } \\
(\rho)\end{array}$ \\
\hline $\begin{array}{l}\text { Setelah } \\
\text { Dilakukan } \\
\text { Promkesi- } \\
\text { Sebelum } \\
\text { Dilakukan } \\
\text { Promkes }\end{array}$ & 11.00 & $-4.208^{\mathrm{b}}$ & 0.000 \\
\hline $\begin{array}{l}\text { Berdas } \\
\text { uji Wilcoxon } \\
\text { Significance } \\
\text { Z hitung (-4, } \\
\text { diketahui bah } \\
\text { kesehatan ten } \\
\text { pada remaja. }\end{array}$ & $\begin{array}{l}\text { an tabel } \\
\text { Test dida } \\
\text { ted) } 0.0 \\
8 \text { ) deng } \\
\text { terdapat } \\
\text { g infek }\end{array}$ & $\begin{array}{l}\text { d1ketanu } \\
\text { oatkan } A \\
00<0.05 \text {, } \\
\text { an demiki } \\
\text { pengaruh } \\
\text { i menular }\end{array}$ & $\begin{array}{l}\text { nasil uj1 } \\
\text { ymptotic } \\
\text { dan nilai } \\
\text { an dapat } \\
\text { promosi } \\
\text { seksual }\end{array}$ \\
\hline
\end{tabular}

\section{PEMBAHASAN}

\section{Karasteristik Responden}

Berdasarkan usia dari sebagian besar reponden berusia diantara 14-16 tahun, dan responden paling sedikit berusia diantara 1720 tahun. Masa remaja adalah saat dimana remaja mengalami perubahan yaitu perubahan dalam sikap, dan perubahan fisik, perubahan baik secara emosi, tubuh, minat, pola perilaku dan berbagai macam masalah-masalah pada masa remaja (Hurlock, 2011; Pratiwi, 2012).

Hal ini didukung oleh penelitian Hurlock (2011), masa remaja dimulai dengan masa remaja awal (12-24 tahun), kemudian dilanjutkan dengan masa remaja tengah (15-17 tahun), dan masa remaja akhir (18-21 tahun). Pada masa peralihan dari kanak-kanak ke remaja berupa peningkatan dalam berpikir abstrak, idealis, dan logis. Ketika mereka mengalami peralihan tersebut, remaja mulai berpikir secara lebih egosentris, sering merasa bahwa mereka berada di panggung, unik, dan tidak terkalahkan (Santrock, 2011).

Berdasarkan jenis kelamin, responden terbanyak berjenis kelamin perempuan. Menurut Hungu (2012) jenis kelamin adalah perbedaan antara laki-laki dan perempuan yang secara biologis sejak seseorang dilahirkan.

Jenis kelamin merupakan salah satu faktor yang berkaitan dengan perilaku berisiko pada remaja. Selain perbedaan karakteristik yang dimiliki laki-laki dan perempuan juga mempengaruhi, dimana perempuan cenderung memiliki sifat feminin seperti cenderung pasif, tidak berterus terang, tidak percaya diri, segan membicarakan seksual dan cenderung lemah lembut. Dengan demikian dalam Kondisi ini Perempuan lebih rentan tertular IMS dibandingkan dengan laki-laki karena saat berhubungan seks, dinding vagina dan leher rahim langsung terpapar oleh cairan sperma. Jika sperma terinfeksi oleh IMS, maka perempuan tersebut bisa terinfeksi (Kusmiran, 2012).

Berdasarkan sumber informasi kesehatan reproduksi, dsri 45 responden yang diteliti. Menunjukan bahwa sebagian besar responden memiliki sumber informasi kesehatan reproduksi yang berasal dari orang tua.

Saat anak beranjak menuju dewasa, remaja membutuhkan informasi terkait dengan perubahan dalam dirinya, baik secara fisik, mental maupun sosial yang tidak terlepas dari fungsi, proses dan sistem reproduksinya (Ristraningsih, 2017).

Orang tua harus menemptakan diri sebagai teman dari anaknya agar anak lebih terbuka dengan orang tua dan merasa nyaman untuk menceritakan apa yang selalu terjadi pada dirinya kepada orang tua dengan begitu orang tua dapat muda mengotrol perkembangan anaknya serta mengajarkan tentang pentingnya melindungi kesehatan reproduksi (Anwar.,dkk, 2020).

Komunikasi yang terjalin baik antara orang tua dan anak dapat menguranggi kecenderungan remaja dari bahaya perilaku seksual beresiko (Kosati, 2018)

Sejalan dengan penelitian yang dilakukan oleh (Ernawati, 2016) dimana hasil yang didapatkan adalah pemanfaatan orang tua sebagai sumber informasi kesehatan reproduksi pada remaja.

\section{Pengaruh Promosi Kesehatan Tentang IMSTerhadap Pengetahuan Remaja}

Berdasarkan hasil penelitian pada tabel 4 diketahui nilai $\rho=0.000<0.05$ yang berarti ada pengaruh Promosi Kesehatan Tentang IMS, Terhadap Pengetahuan Remaja di SMA YPK Diaspora Kotaraja Jayapura. Berdasarkan penelitian yang dilakukan oleh Bazarudia (2013), meneliti tentang Efektivitas Penyuluhan Kesehatan Reproduksi Remaja Terhadap tingkat pengetahuan Siswa SMA N 6 Kecamatan Pontianak Timur Tahun 2013 dari hasil Uji wilcoxon penelitian ini didapatkan nilai signifikan (sig) sebesar $0.000(\mathrm{p}=<0.05)$. Nilai $\mathrm{p}=<0.05$ menunjukan bahwa terdapat perbedaan yang bermakna antara skor sebelum 
penyuluhan dengan skor setelah penyuluhan. Dapatdibuktikan bahwa penyuluhan kesehatan yang baik akan memberikan peningkatan pengetahuan siswa terhadap kesehatan reproduksi remaja.

Menurut Johariyah \& Mariati (2018), menyebutkan bahwa meningkatkan pengetahuan responden diperlukan pendidikan kesehatan melalui penyuluhan, seperti penyuluhan kesehatan tentang kesehatan reproduksi remaja yang dilakukan secara efektif dan efesien yang diberikan baik visual maupun audio visual, sehingga pengetahuan akan mudah diingat.

Untuk meningkatkan pengetahuan responden tentang kesehatan reproduksi remaja dapat dilakukan dengan penyampaian informasi, dalam Notoatmodjo (2014), penyampaian informasi dipengaruhi oleh metode dan media yang digunakan yang mana metode dan media penyampaian informasi dapat memberikan efek yang signifikan.

Setelah dilakukan perhitungan rata- rata pada jawaban responden, pernyataan yang paling rendah skornya sebelum dilakukan promosi kesehatan adalah nomor 19 dengan total jawaban salah berjumlah 30 yaitu pernyataan "Konseling dibutuhkan dalam penanganan terhadap IMS". Kemudian hasil yang di dapatkan setelah dilakukan promosi kesehatan, pernyataan yang paling rendah ratarata skornya adalah nomor 20 dengan total jawaban salah berjumlah 21 yaitu pernyataan "Konseling hanya diperlukan sesudah tes HIV, sebelum tes tidak perlu diberikan konseling".

Wawan \& Dewi (2011), Pengetahuan merupakan hasil tahu yang diperoleh melalui penglihatan ataupun pendengaran dan juga pengetahuan dipengaruhi oleh pendidikan. Penyampaian informasi dipengaruhi oleh metode dan media yang digunakan yang mana metode dan media penyampaian informasi dapat memberikan efek yang signifikan terhadap peningkatan pengetahuan dan sikap.

Menurut peneliti, ini menandakan bahwa pengetahuan remaja mengenai pentingnya dilakukan konseling mengenai status kesehatan dan program pencegahan penyakit menular seksual seutuhnya belum sesuai yang diharapkan. Permasalahan remaja yang berkaitan dengan kesehatan reproduksi sering kali berawal dari kurangnya informasi, pemahaman dan kesadaran untuk mencapai keadaan sehat.

Pernyataan yang paling tinggi skornya sebelum dilakukan promosi kesehatan pada kuesioner nomor tujuh dengan total jawaban benar berjumlah 39 yaitu pernyataan "Jika mengalami keputihan yang tidak wajar harus segera diperiksakan ke fasilitas pelayanan kesehatan". Kemudian pernyataan yang paling tinggi skornya setelah dilakukan promosi kesehatan pada kuesioner nomor tujuh dengan total jawaban benar berjumlah 41 yaitu pernyataan "Jika mengalami keputihan yang tidak wajar harus segera diperiksakan ke fasilitas pelayanan kesehatan".

Menurut, Anwar., dkk, (2020) Kesehatan reproduksi adalah keadaan kesejahteraan fisik, mental, dan sosial yang utuh dan bukan hanya tidak adanya penyakit dan kelemahan, dalam segala hal yang berhubungan dengan sistem reproduksi dan fungsi-fungsi serta prosesprosesnya. Minimnya pengetahuan mengenai proses-proses reproduksi, pentingnya menjaga kebersihan alat reproduksi, dan dampak dari perilaku yang tidak bertanggung jawab menyebabkan sebagian remaja mengalami masalah-masalah seperti remaja kurang menyadari akan pentingnya menjaga kesehatan reproduksinya dan gejala-gejala yang ditimbulkan akibat gangguan pada sistem reproduksinya.

Menurut peneliti, kurangnyapengetahuan remaja mengenai masalah kesehatan yang dihadapinya, seperti gangguan- gangguan pada sistem reproduksinya misalnya keputihan, adalah wujud dari kurangnya informasi mengenai kesehatan reproduksi, baik dari pihak orang tua dan sekolah menjadi penentu tinggi rendahnya tingkat pengetahaun remaja mengenai IMS melalui upaya komunikasiyang dilakukan. Upaya menjaga Kesehatan reproduksi merupakan suatu hal yang harus bersifat kooperatif dari berbagai aspek seperti diri sendiri, pihak orang tua, sekolah dan lingkungan masyarakat yang harus diimbangi oleh norma agama dan sosial,untuk melindungi kesehatan reproduksi pada anak. Berdasarkan hasil penelitian, tingkat pengetahuan sebelum dilakukan promosi kesehatan adalah 2 atau $4.4 \%$ memiliki pengetahuan baik dan 14 responden atau $31.1 \%$ memiliki pengetahuan cukup. Kemudian setelah dilakukan promosi kesehatan didapatkan 17 responden atau $37.8 \%$ memiliki pengetahuan baik, 20 responden atau $44.4 \%$ memiliki pengetahuan cukup dan 8 responden atau $17.8 \%$ memiliki pengetahuan kurang.

Menurut (Notoatmodjo, 2012), dilihat 
dari hasil analisis penelitian di atas yang menunjukkan terjadi peningkatan pengetahuan dan sikap sebelum dan sesudah diberikan promosi kesehatan tentang penyakit menular seksual, hal ini membuktikan bahwa metode promosi kesehatan efektif digunakan untuk meningkatkan pengetahuan pelajar tentang penyakit menular seksual.

Menurut peneliti, meningkatnya tingkat pengetahuan remaja adalah dampak dari dilakukannya promosi kesehatan melalui video edukasi, remaja adalah kategori usia yang perlu medapatkan perhatian serius agar mereka tidak melakukan tindakan perilaku seksual menyimpang, hal ini sangat penting dilakukan untuk mencegah timbulnya perilaku seks bebas yang dapat menjadi penyebab timbulnya masalah IMS bahkan dapat berlanjut enjadi infeksi HIV/ AIDS di kalangan remaja. timbulnya kelainan-kelainan terutama pada alat kelamin.

Menurut Oktiva (2010), menyebutkan bahwa pengetahuan remaja tentang seks bebas terdapat hubungan yang sedang terhadap sikap remaja terhadap seks bebas. Hasil penelitian tersebut didukung oleh penelitian Puspitaningrum dan Damayanti (2012) yang menyebutkan bahwa responden yang memiliki pengetahuan yang baik mendorong perilaku yang positif dalam pencegahan seks bebas. Responden yang mendapatkan informasi dan edukasi yang ketat dari orang tua dan sekolah tentang pencegahan seks bebas, cenderung berperilakumencegah seks bebas.

Pada saat peneliti melakukan promosi kesehatan, peneliti menggunakan metode video edukasi. Peneliti memilih video edukasi inikarena mengingat masa pandemic covid-19 saat ini jadi walaupun tidak bertemu secara langsung namun responden dapat menonton video edukasi dan memahami informasi tentang IMS yang disampaikan oleh peneliti sehingga mempengaruhi tingkat pengetahuan responden.

Oleh sebab itu promosi kesehatantentang IMS ini sangat penting agar remaja lebih mengetahui dan meningkatkan pengetahuan tentang cara menjaga kesehatan reproduksi sejak dini dan mengaplikasikannya di kehidupan sehari-harinya, serta mengetahui penyakit- penyakit yang terjadi jika mereka tidak menjaga kesehatan reproduksinya. Melalui upaya peningkatan peningkatan promosi kesehatan serta penerapan prinsip bimbingan konseling oleh guru BK di harapkan dapat memutuskan rantai penularan
IMS pada remaja.

\section{KESIMPULAN}

Berdasarkan hasil dan pembahasan mengenai pengaruh promosi kesehatan tentang Infeksi Menular Seksual (IMS) terhadap pengetahuan siswa/i SMA YPK Diaspora Kotaraja, maka dapat disimpulkan.

1. Dari hasil penelitian diketahui tingkat pengetahuan siswa/i sebelum dilakukannya promosi kesehatan mengenai IMS, dari 45 responden yang diteliti sebanyak 2 responden $(4,4 \%)$ memiliki pengetahuan kurang, 14 responden $(31,1 \%)$ memiliki pengetahuan cukup, dan 29 responden $(64,4 \%)$ memiliki pengetahuan baik. Dari hasil penelitian diketahui tingkat pengetahuan siswa/i setelah dilakukannya promosi kesehatan mengenai IMS, dari 45 responden yang diteliti sebanyak 17 responden $(37,8 \%)$ memiliki pengetahuan baik, 20 responden $(44,4 \%)$ memiliki pengetahuan cukup, dan 8 responden $(17,8 \%)$ memiliki pengetahuan kurang.

2. Dari hasil penelitian diketahui terdapat hubungan antara promosi kesehatan tentang IMS, terhadap pengetahuan remaja di SMA YPK Diaspora Kotaraja Jayapura, hal ini ditunjukan dari hasil uji Wilcoxon $\rho$ (Asymp. Sig. 2-tailed) $=0,000<$

0.05 yang menunjukan ada pengaruh yang dilakukan.

\section{DAFTAR PUSTAKA}

Anwar. dkk. (2020). Hubungan Pengetahuan dan Peran Keluarga dengan Perilaku Remaja Putri dalam Menjaga Kesehatan Reproduksi di SMP Negeri 1 Kuta Baro Aceh Besar. Journal of Healthcare Technology and Medicine Vol. 6 No. 1 April 2020 Universitas Ubudiyah Indonesia e-ISSN : 2615109X.

Arikunto, S. (2012). Dasar-dasar Evaluasi Penelitian. Jakarta: Bumi aksara.

Astuti, D. Y. (2017). Hubungan Tingkat Pengetahuan dengan Kejadian Infeksi Menular Seksual pada Wanita Usia Subur di Puskesmas Sleman Tahun 2016. Skripsi Online. Politeknik Kesehatan Kementrian Kesehatan. Jokjakarta.

Bachruddin, W. (2017). Pengaruh Penyuluhan Tentang Bahaya Seks Bebas Terhadap 
Pengetahuan Remaja Tentang Seks Bebas Di Sma Negeri Binsus 9 Manado. Program Studi Ilmu Keperawatan Fakultas Kedokteran Universitas Sam Ratulangi.

Buzarudia, F. (2013). Efektivitas Penyuluhan Kesehatan Reproduksi Remaja Terhadap Tingkat Pengetahuan Siswa SMAN 6 Kecamatan Pontianak Timur Tahun 2013. Naskah Publikasi. Program Studi Pendidikan Dokter Fakultas Kedokteran Universitas Tanjungpura 2013.

Daili, S. dkk. (2011). Buku Ajar Ilmu Penyakit Kulit dan Kelamin. Fakultas Kedokteran Universitas Indonesia. Hal 363-365. Edisi ke-5, Cetakan ke4. Jakarta.

Desi, M. N. dkk. (2018). Perilaku Seksual Berisiko pada Pedagang Bawang Merah di Kecamatan Wanasari Kabupaten Brebes. Jurnal Promosi Kesehatan Indonesia Vol. 13 /No. 1 / Januari 2018, Semarang. [Online] Tersedia di https://ejournal.undip.ac.id/index.php/ jpki/art icle/view/19049/13272 [Diakses : 31 April 2019].

Dewi, M. dkk. (2017). Analisis Strategi Promosi Kesehatan dalam Rangka Meningkatkan Kesadaran Hidup Sehat oleh Rumah Sakit Jiwa Daerah Dr. RM. Soedjarwadi Provinsi Jawa Tengah. Jurnal komunikasi P-ISSN: 1907-898X, E-ISSN: 2548-7647 Volume 12,Nomor 1, Oktober 2017. Universitas Islam Indonesia.

Dinkes Kota Jayapura. (2018). Informasi Penanggulangan IMS [Online] Tersedia di https://www.pasificpos.com/item/279 24- pemerintah-kota-jayapura-bahaspencegahan-ims. [Diakses : $01 \mathrm{Mei}$ 2019].

Djuanda, A. dkk. (2011). Ilmu Penyakit Kulit dan Kelamin. Edisi 6. Jakarta: Fakultas Kedokteran Universitas Indonesia. p. 3-4, 7-8.

Ervina, A. dkk. (2015). Hubungan Jenis Kelamin Dan Sumber Informasi Dengan Pengetahuan Remaja Mengenai Penyakit Menular Seksual (Pms). E-Jurnal Obstretika. Vol. 3, No. 1. AKBID La Tansa Mashiro, Rangkasbitung.
Gross, G., \& Tyring, S. K. (2011). Sexually Transmitted Infection and Sexually Transmitted Disease. Berlin: Springer.

Handsfield, H. H. (2011). Color Atlas \& Synopsis of Sexually Transmitted Disease (3rd ed.). McGraw-Hill.

Herlina. (2013). Babliotherapy: Mengatasi Masalah Anak dan Remaja melalui Buku. Bandung: Pustaka Cendekia Utama.

Howell, L. (2009). Segala Sesuatu yang Perlu Diketahui tentang Tubuh Manusia. LunaPublisher. Jogjakarta

Hurlock. E. B. (2011). Psikologi Perkembangan: Suatu Pendekatan Sepanjang Rentan Kehidupan. Jakarta: Erlangga.

Irham, M. \& Wilyani, N. A. (2013). Psikologi Pendidikan.Teori dan aplikasi dalam proses pembelajaran. Jogjakarta: Arruzz Media.

Johariyah, A \& Mariati, T. (2018). Efektivitas Penyuluhan Kesehatan Reproduksi Remaja Dengan Pemberian Modul Terhadap Perubahan Pengetahuan Remaja. Jurnal Manajemen Kesehatan Yayasan RS.Dr.Soetomo Vol.4 No.1 April 2018 : 38- 46.

Kalangi, R.., dkk. (2018). Pengaruh Penyuluhan Kesehatan terhadap Tingkat Pengetahuan dan Sikap Pelajar tentang Penyakit Menular Seksual di SMK Trinita Manado. Fakultas Kesehatan Masyarakat Universitas Sam Ratulangi.

Kemenkes RI. (2014). Situasi dan Analisis HIV AIDS. Jakarta: Kemenkes RI

Kosati, T. S. (2018). Hubungan antara peran Orang tua, Teman sebaya dan Religiusitas dengan Perilaku Seksual beresiko pada Remaja awal di SMP Negeri" A" Surabaya. Skripsi online. Fakultas Keperawatan Universitas Airlangga Surabaya.

Kusmiran E. (2012). Kesehatan Reproduksi Remaja dan Wanita. Penerbit Salemba Medika. Jakarta.

Nari J, Shaluhiyah Z \& Nugraha P. (2015). Analisis Faktor-Faktor yang Berhubungan dengan Kejadian IMS pada Remaja di Klinik IMS Puskesmas Rijali dan Passo Kota Ambon. Jurnal Promosi Kesehatan Indonesia Vol. 10 / No. 2 / Agustus 
2015.

Notoadmodjo, Soekidjo. (2014). Promosi Kesehatan Dan Prilaku Kesehatan. Jakarta: Rineka Cipta.

Notoatmodjo, S. (2012). Promosi kesehatan dan Perilaku Kesehatan. Jakarta: Rineka cipta.

Notoatmodjo,S. (2010). Promosi Kesehatan dan Ilmu Perilaku. Jakarta: PT Rineka Cipta.

Nova. (2016). Hubungan Pendidikan dan Pengetahuan dengan Kejadian Infeksi Menular Seksual pada Klien di Wilayah Kerja Puskesmas Penurunan Kota Bengkulu Tahun 2014. Akademi Kesehatan Sapta Bakti. Published: Thursday, 07 January 2016 07:57 hits :386.

Oktiva, Y.D. \& Muhlisin, A. (2010). Hubungan antara Tingkat Pengetahuan tentang Kesehatan Reproduksi Remaja dan Pola Asuh Orang Tua dengan Sikap Remaja tentang Seks Bebas di SMAN 1 Tawangsari Sukoharjo.

Potter, P. A. \& Perry, A. G. (2013). Fundamentals of nursing: concepts, process, and practice. (8ed). St. Louis, MI: Elsevier Mosby.

Purnomo., B. B.(2011). Dasar-dasar Urologi. 2nd ed. Jakarta: CV. Sagung Seto; 2003.

Puspitaningrum, D. \& Damayanti, F.N. (2012). Analisis Faktor-Faktor yang Memengaruhi Remaja Putri dengan Perilaku Pencegahan Seks Bebas. Jurnal Kebidanan dan Keperawatan, $8,101-110$.

Rahmi, U., dkk, (2015). Pengetahuan Siswa Kelas XI Tentang Penyakit Menular Seksual. Jurnal Keperawatan Indonesia. Volume 1. Nomor 2. Desember 2015.

Ratna, D., dkk, (2016). Pencegahan Infeksi MenularSeksual Melalui Penyuluhan Dan Simulasi Penggunaan Kondom Pada Pekerja Seksual Di Klinik Mentari Puskesmas Panjang Bandar Lampung. Laporan Pengabdian Kepada Masyarakat. Fakultas KedokteranUniversitas Lampung.

Respati, W.S. (2013). Problematika Remaja kibat Kurangnya Informasi
Kesehatan Reproduksi. Journal Ilmiah Bunga Rampai, Vol. 7 No. 1 Januari 2013.

Ristraningsih, G.P. (2017). Pengaruh Pendidikan Kesehatan Terhadap Tingkat Pengetahuan Kesehatan Reproduksi Remaja Pada Siswi Kelas VIII di SMP Negeri 28 Semarang. Surakarta:Universitas Muhammdiyah.

Sarwono S.W. (1999). Pergeseran Norma Perilaku Seksual Kaum Remaja. CV. Rajawali.Jakarta.

Sarwono, S. (2011). Psikologi Remaja. Jakarta: Rajagrafindo Persada.

Sugiyanti, T. Y. (2019). Metode Focus Group Discussion Terhadap Peningkatan Pengetahuan Kesehatan ReproSduksi pada Remaja Putri di BPM Widi Utami Puring. Karya Tulis Ilmiah. Sekolah Tinggi Ilmu Kesehatan Muhammadiyah. Gombong.

Susilowati,D.(2016).PromosiKesehatan.Kemenke s RI.

Tuntun, M. (2018). Faktor Resiko Penyakit Infeksi Menular Seksual(IMS).Jurnal Analis Kesehatan, Politeknik Kesehatan Tanjungkarang,Indonesia [Online]Tersediadihttps://ejurnal.polte kkes-

tjk.ac.id/index.php/JK/article/downloa d/1109/ 811 [Diakses: 29 April 2019].

Umami, I. (2010). Psikologi Remaja. Diterbitkan oleh Penerbit IDEA Press Yogyakarta.

Wawan, A., \& Dewi, M. (2010). Teori dan Pengukuran Pengetahuan, Sikap dan Perilaku Manusia. Yogyakarta: Nuha Medika.

WHO. (2019). Developing a Report Health for The World's Adolescents. Available: http:// www.who.int/ maternal - child -adolescent / topics / adolescent / reproductivehealth, diakses tanggal 13 Agustus 2019.

Zatalini, D.S., \& Wulandari, R. D. (2018). Pengaruh Penyuluhan dengan Metode Diskusi, Poster dan Video Terhadap Tingkat Pengetahuan Tentang Penyakit Menular Seksual padaAnak Jalanan Kota Semarang. Studi Kasus di Rumah Pintar Bang Jo. Jurnal KedokteranDiponegoroVolume7,Nom or $2, \quad$ Mei 2018. 